\title{
Nutrients Utilization and Haematological Indices of Sokoto Red Goats Fed Maize Cob Replacing Maize Bran with Cowpea Husk Basal Diet
}

\author{
Babale $\mathrm{DM}^{1^{*}}$, Yahaya $\mathrm{MS}^{2}$, Nyako $\mathrm{HD}^{3}$ and Mbahi $\mathrm{TF}^{3}$ \\ ${ }^{1}$ Department of Animal Production, Adamawa State University, Mubi, Nigeria \\ ${ }^{2}$ Department of Animal Science, Taraba State University, Jalingo, Nigeria \\ ${ }^{3}$ Department of Animal Science, Modibbo Adama University of Technology, Yola, Adamawa State, Nigeria
}

*Corresponding author: Babale DM, Department of Animal Production, Adamawa State University, Mubi, Nigeria, Tel: 07033747191, E-mail: babaled@yahoo.com

Citation: Babale DM, Yahaya MS, Nyako HD, Mbahi TF (2018) Nutrients Utilization and Haematological Indices of Sokoto Red Goats Fed Maize Cob Replacing Maize Bran with Cowpea Husk Basal Diet. J Adv Plant Sci 1: 103

Article history: Received: 18 March 2018, Accepted: 31 May 2018, Published: 01 June, 2018

\begin{abstract}
Experiment was conducted to determine the effects of feeding maize bran, maize cob and cowpea husk on feed utilization and hematological indices of Red Sokoto goats. Twenty four (24) bucks with average age and weight of 12 months and $12.00 \mathrm{Kg}$ respectively were randomly subjected to six (6) dietary treatments each having four replicates. The diets consisted of maize cob replacing maize bran at $0,10,20$, 30,40 , and $50 \%$ levels designated as $\mathrm{T}_{1}, \mathrm{~T}_{2}, \mathrm{~T}_{3}, \mathrm{~T}_{4}, \mathrm{~T}_{5}$ and $\mathrm{T}_{6}$ respectively in a Randomized Complete Block Design (RCBD. Cowpea husk was given to all animals ad libitum as basal diet. Adaptation period of 14 days was followed by 84 days of data collection. Animals were confined in metallic metabolism cages for metabolic trial for 14 days. Feeds and faecal samples were analyzed for their proximate composition using standard procedures. Urines were collected to determine their nitrogen contents. Parameters determined were dry matter intakes, weight gains, digestibility, feed efficiencies, protein/nitrogen intakes and retention. Haematological indices considered were packed cell volume (PCV), red blood cell counts (RBC), white blood cell counts (WBC), total protein (TP), Albumin, Globulin and blood glucose/urea. Dry matter intake $(\mathrm{DMI})$ and Faecal output $(\mathrm{FO})$ were significantly $(\mathrm{P}<0.05)$ affected with treatments $\mathrm{T}_{1}$ and $\mathrm{T}_{6}$ having the highest and least DMI of $408.86 \mathrm{~g}$ and $313.57 \mathrm{~g}$ respectively. Faecal output had $\mathrm{T}_{1}(134.64 \mathrm{~g})$ highest and $\mathrm{T}_{4}(110 \mathrm{~g})$, the least. No significant difference occurred across treatments for protein intakes, faecal protein/nitrogen, nitrogen retention and retention as percentage of intakes. For hematological indices, values for PCV, RBC, WBC, Blood urea, blood protein and glucose fell within the normal ranges for healthy goats. In conclusion, the diets up to $50 \%$ maize cob inclusion were found to supply the needed nutrients which enabled the animals utilize feeds effectively, increased weights and maintain the normal healthy blood profiles.
\end{abstract}

Keywords: Feeds; Utilization; Haematological Indices; Red Sokoto Goats

\section{Introduction}

In most parts of the world, protein is specially the major nutrient deficient in people's diets. It is reported that an average Nigerian consumes about $5.5 \mathrm{~g}$ of animal protein per day which is by far lower than the recommended $77 \mathrm{~g}$ per day [1]. The low level of animal protein intake in Nigeria is due to the low level of productivity of our livestock and high cost of animal protein.

In Nigeria, goats contributed about $24 \%$ of meat supply [2]. Therefore, the development of a virile goat industry will lead to increased level of animal protein intakes of our people. This will require the development of highly productive animals through genetic improvement, proper health care and nutrition.

In producing maize flour for human consumption, maize bran, a by-product of the industry is available for animal feed. Maize bran is high in cell wall content, Neutral Detergent Fibre (NDF) (60\%), primarily hemi-cellulose (90\% of NDF). Such feed with high cell wall content but poorly lignified will have increased surface area for microbial activity in the rumen and thus increased digestibility when ground [3]. It is reported that maize bran has crude protein (CP) content of 10.18\%, 12.73\%, with Crude fibre (CF) of $27.10 \%$, Neutral Detergent fibre (NDF) of $45.1 \%$ and energy content of $6.32 \mathrm{Kcal} / \mathrm{g}$ GE and $250 \mathrm{Kcal} / \mathrm{kg} \mathrm{ME} \mathrm{coupled} \mathrm{with}$ its $88 \%$ feeding value of maize, it can be used in feeding ruminants as an energy source [4-7].

Maize cob is generally used as fire wood in small scale farms but wasted on large scale farms [8]. It is readily available since the cobs are shelled at home stead or granaries which therefore, do not require transportation. It has medium density and easy to store. 
Urior and Kategile also reported that the output is good when ground and can be easily mixed with other feed ingredients [8]. The nutrients contents of maize cob have been reported (3\% CP, 85\% cell wall, 93.96\% NDF, 38.01\% cellulose and $17 \mathrm{Kcal} / \mathrm{g}$ GE [9-11]. Cowpea husk is a legume by-product, a portion of the whole pod which on threshing, remains as wastes when the seeds are removed. The reported nutrients contents of Cowpea husk include dry matter (DM) of 92.29\%, 90.83\% with crude protein (CP) of $12.69 \%$ and $12.25 \%$ [4,12]. Also the NDF is $71.44 \%, 58.91 \%$ and $4.5 \mathrm{Kcal} / \mathrm{g} \mathrm{GE}[4,11,13]$. It is highly accepted by goats but has a depressing effect on feed intake [4].

Efficiency of feed utilization is a function of feed composition, level of feed intake and production needs [14]. Rate of gain and feed efficiency are equally important characteristics in goat performance. The higher the energy contents of feed, the more favorable the feed efficiency [15].

It is reported that an inverse relationship exists between nutrient consumption and digestibility [16]. There is poor degree of utilization of nutrients with reduced ratio of concentrates in the diet [17]. That nitrogen excreted in urine depends on urea recycling and efficiency of utilization of ammonia produced in the rumen by microbes for microbial protein synthesis. Therefore, the percentage nitrogen digestibility and retention decrease with increase in the level of roughage and decrease in the level of crude protein in the diet.

Ojebiyi, et al. also reported that a readily available and fast means of assessing clinical and nutritional status of animals on feeding trials is the use of blood analysis [18]. That ingestion of dietary components has measurable effects on the blood composition. This may be considered an appropriate measure of long term nutritional status of the animals. Therefore, haematological values of farm animals are greatly affected by nutritional status.

Blood analysis is important because it contains a myriad of metabolites and other constituents which provide a valuable medium for clinical investigation and nutritional status of human beings and animals [19]. Blood is used in nutritional evaluation and health survey of animals. According to Yusuf, et al., the blood profile of animals often reflects their nutritional adequacy or otherwise [20]. Therefore, dietary components have measurable effects on blood constituents such that significant changes in their values can be used to draw inferences on the nutritive values of feeds offered to the animals.

Information on the nutrients utilization and its effects on blood indices on red Sokoto goats fed replacement levels of maize cobs for maize bran with cowpea husk basal diet are scanty. The study was therefore carried out to determine the nutrient composition of the feed ingredients, their effects on nutrient availability and utilization and haematological indices of Red Sokoto goats receiving the various feeds.

\section{Materials and Methods}

\section{Experimental site}

The experiment was conducted at the Teaching and Research Farm of the Faculty of Agriculture, Adamawa State University, Mubi, Nigeria. Mubi is situated in the northern part of Adamawa State on Latitude $90^{\circ} 11^{\mathrm{I}}$ north of the equator and Longitude $13^{\circ} 45^{\mathrm{I}}$ east of the Greenwich Meridian at an altitude of $696 \mathrm{~m}$ above sea level. It has a land area of 4,728.77 $\mathrm{m}^{2}$ and population of 245,460 , Mubi region falls within the Sudan Savanna vegetation zone of the country [21].

\section{Experimental animals and their management}

Twenty four Red Sokoto bucks of average age of 12 months and mean live weight of $12 \mathrm{~kg}$ were sourced from the local markets in and around Mubi. Their ages were determined through their dental formulae. They were then housed individually in pens measuring $1.5 \mathrm{~m}^{2}$ and $1.5 \mathrm{~m}$ high. The floor of the house was of concrete and covered with wood shavings to absorb moisture from the animals' dung and urine. Towards the end of the experimental periods, metallic metabolism cages were used to individually house the animals for digestibility trials.

The animals were quarantined for two weeks during which they were fed the experimental diets for adaptation and dewormed with Albendazol. At the end of the adaptation period, the animals were tagged, randomly allocated to treatments and balanced on weight basis for all the treatments. They were weighed to get the initial weights before embarking on data collection.

\section{Experimental Diets}

There were six treatments with each treatment replicated four times, making a total of twenty four experimental animals. The experimental diets $(\mathrm{T})$ consisted of:

$\mathrm{T}_{1}: 90 \%$ Maize bran $+10 \%$ Cotton seed cake, $\mathrm{T}_{2}: 80 \%$ Maize bran $+10 \%$ corn cobs $+10 \%$ cotton seed cake, $\mathrm{T}_{3}: 70 \% \mathrm{Maize}$ bran $+20 \%$ corn cobs $+10 \%$ cotton seed cake, $\mathrm{T}_{4}: 60 \%$ Maize bran $+30 \%$ corn cobs $+10 \%$ cotton seed cake, $\mathrm{T}_{5}: 50 \%$ Maize bran $+40 \%$ corn cobs $+10 \%$ cotton seed cake, $\mathrm{T}_{6}: 40 \%$ Maize bran $+50 \%$ corn cobs $+10 \%$ cotton seed cake. The above formed the concentrate diets for the experiment. The corn cobs which were included at graded levels of 0, 10, 20, 30, 40 and 50\% in the six diets replaced Maize bran weight for weight. These formed the supplement portions and were fed to the animals at $150 \mathrm{~g} / \mathrm{head} / \mathrm{day}$. The cowpea husk formed the basal diet and was fed ad libitum. The experimental diets were as presented in Table 1. Randomized Complete Block Design (RCBD) was employed in the study (Table 2). 


\begin{tabular}{|c|c|c|c|c|}
\hline \multicolumn{5}{|c|}{ Feed } \\
\hline Nutrients & MBR & CB & CSC & CPHK \\
\hline Dry matter (DM) (\%) & 88.72 & 87.65 & 95.32 & 90.81 \\
\hline Crude protein (CP) (\%) & 10.22 & 4.88 & 40.20 & 12.25 \\
\hline Crude fiber (CF) (\%) & 27.10 & 41.82 & 26.20 & 30.79 \\
\hline Ash (ASH) (\%) & 3.69 & 7.90 & 3.92 & 7.84 \\
\hline $\mathbf{N}_{\mathbf{2}}$ Free extract (NFE) (\%) & 51.76 & 39.80 & 20.88 & 42.96 \\
\hline Ether extract EE (\%) & 7.23 & 5.60 & 7.80 & 6.13 \\
\hline Met. Energy ME (Kcal/g) & 6.32 & 7.22 & 5.82 & 4.50 \\
\hline
\end{tabular}

$\mathrm{MBR}=$ Maize bran, $\mathrm{CB}=$ Corn cob, $\mathrm{CSC}=$ Cotton seed cake, $\mathrm{CPHK}=\mathrm{Cow}$ pea husk

Table 1: Analyzed chemical composition of feed ingredients

\begin{tabular}{|c|c|c|c|c|c|c|}
\hline \multicolumn{7}{|c|}{ TREATMENTS } \\
\hline Feed & $\mathrm{T}_{1}(10 \% \mathrm{MC})$ & $\mathrm{T}_{2}(10 \% \mathrm{MC})$ & $\mathrm{T}_{3}(20 \% \mathrm{MC})$ & $\mathrm{T}_{4}(30 \% \mathrm{MC})$ & $\mathrm{T}_{5}(40 \% \mathrm{MC})$ & $\mathrm{T}^{6}(50 \% \mathrm{MC})$ \\
\hline MCB (\%) & 0 & 10 & 20 & 30 & 40 & 50 \\
\hline MBR (\%) & 90 & 80 & 70 & 60 & 50 & 40 \\
\hline CSC (\%) & 10 & 10 & 10 & 10 & 10 & 10 \\
\hline СРНК & ad lib & ad lib & ad lib & ad lib & ad lib & ad lib \\
\hline \multicolumn{6}{|c|}{ Analyzed Nutrients composition } & \\
\hline \multicolumn{7}{|l|}{ Nutrients } \\
\hline M.E.(Kcal/g) & 5.208 & 5.244 & 5.280 & 5.316 & 5.352 & 5.388 \\
\hline CP (\%) & 12.84 & 12.41 & 12.20 & 11.99 & 11.78 & 11.58 \\
\hline CF (\%) & 29.28 & 29.87 & 30.46 & 31.04 & 31.60 & 32.25 \\
\hline ASH (\%) & 6.23 & 6.39 & 6.56 & 6.57 & 6.90 & 7.07 \\
\hline $\mathrm{EE}(\%)$ & 6.59 & 6.51 & 6.46 & 6.39 & 6.33 & 6.28 \\
\hline NFE (\%) & 45.06 & 44.82 & 44.32 & 44.01 & 43.39 & 42.82 \\
\hline
\end{tabular}

$\mathrm{MR}=$ Maize bran, $\mathrm{CB}$-Corn cobs, $\mathrm{CSC}=$ Cotton seed cake, $\mathrm{CPHK}=$ Cowpea husk, $\mathrm{ME}=\mathrm{Metabolizeable} \mathrm{energy,} \mathrm{CP}=\mathrm{Crude}$ protein, $\mathrm{CF}=$ Crude fiber, $\mathrm{EE}=$ Ether extract, NFE=Nitrogen free extract

Table 2: Composition of Experimental Diets

\section{Parameters Measured}

Parameters determined were proximate compositions of feed ingredients, daily dry matter intakes, and daily weight changes, digestibility of treatment diets, feed efficiencies, nutrients utilization and hematological indices. Proximate compositions were determined using the methods described by AOAC (2005) [22]. Metabolizeable were determined using bomb calorimeter.

In determining the feed and nutrients utilization, the diets under investigation were given to the animals in known amounts. Each of the animals was restrained in steel metabolism cages designed to collect urine and feces separately. Urine was collected in $10 \mathrm{~N} \mathrm{H}_{2} \mathrm{SO}_{4}$ and the volume for each animal was measured and sampled daily for a period of fourteen days. Fecal outputs were also collected and weighed daily. The proximate compositions of faeces were determined using the methods described by AOAC (2005) [22].

Protein and Nitrogen levels in feed, faeces and urine were determined by standard Kjeldahl procedure [22]. Two samples were collected from each treatment.

Hematological parameters were determined by drawing $10 \mathrm{mls}$ of blood from jugular veins of each animal into a sample bottle containing anticoagulant, Ethylene Diamine Tetra acetic Acid (EDTA). These samples were used for the determination of the packed cell volume (PCV), Haemoglobin (Hb) concentration, Red blood cell counts (RBC) and White blood cell counts (WBC). The Total serum protein, Serum albumin, globulin and blood glucose were determined in the blood serum. The serum was obtained by allowing the blood to coagulate in order to separate the serum and cells.

Packed cell volume was measured for each animal using the micro haematocrit method. Haemoglobin concentration was also measured using the Sahl's (acid haematin) method [23]. Red blood cells were determined with the aid of Neubaur counting chamber (Haemocytometer). Blood smears were used for total white blood cell (WBC) counts determination. Serum samples were also taken and used in the determination of serum urea, total cholesterol, total protein and albumin as described by Fasuyi, et al. [24].

All data obtained were subjected to analysis of variance (ANOVA) using the SAS (2001) package [25]. Means were separated using the Duncan's multiple range test Duncan, 1955. 


\section{Results and Discussion}

The proximate composition of feed ingredients is presented in Table 1.

The effects of treatment diets on nutrients utilization are presented in Table 3. Dry matter intake (DMI) significantly $(\mathrm{P}<0.05)$ decreased with increase in maize cob inclusion in the diets. This followed the same trend with fecal output. There was no significant difference $(\mathrm{P}>0.05)$ in urinary output and feed digestibility between treatments. In terms of protein intake, fecal protein and nitrogen intake, there was no significant difference $(\mathrm{P}>0.05)$ between treatments $\mathrm{T}_{2}-\mathrm{T}_{4}$. However, there were significant difference $(\mathrm{P}<0.05)$ between them and treatments $\mathrm{T}_{1}$ and $\mathrm{T}_{6}$. As for nitrogen retention and nitrogen retained as percentage of intake, only treatment $\mathrm{T}_{6}(50 \%$ maize cobs) differed significantly $(\mathrm{P}<0.05)$ with the rest of the treatments. The performance of the animals confirms the findings of Gibson that goats have high digestive efficiency for cellulose [26]. They are inquisitive feeders with high efficiency in energy and protein conversion. The ability of goats to eat feedstuffs that are not normally eaten by or accessible to other ruminants enhances their overall competitive efficiency.

\begin{tabular}{|c|c|c|c|c|c|c|c|c|}
\hline \multicolumn{9}{|c|}{ TREATMENTS } \\
\hline Parameters & $\mathrm{T}_{1}$ & $\mathrm{~T}_{2}$ & $\mathrm{~T}_{3}$ & $\mathrm{~T}_{4}$ & $T_{5}$ & $T_{6}$ & SEM & Sig Level \\
\hline DMI (g) & $407.86^{\mathrm{a}}$ & $366.07^{\mathrm{b}}$ & $349.29^{b}$ & $363.21^{\mathrm{b}}$ & $352.50^{\mathrm{b}}$ & $313.57^{c}$ & 10.748 & * \\
\hline FOPT(g) & $134.64^{\mathrm{a}}$ & $121.43^{\mathrm{b}}$ & $120.00^{\mathrm{b}}$ & $110.00^{c}$ & $120.00^{\mathrm{b}}$ & $114.29^{\circ}$ & 6.5638 & * \\
\hline U. Vol(mls) & $302.86^{\mathrm{b}}$ & $323.57^{\mathrm{a}}$ & $290.00^{c}$ & $306.07^{b}$ & $303.21^{\mathrm{b}}$ & $308.57^{\mathrm{b}}$ & 8.9407 & * \\
\hline Dig. (\%) & $66.75^{\mathrm{a}}$ & $64.89^{\mathrm{a}}$ & $67.54^{\mathrm{a}}$ & $68.71^{a}$ & $64.11^{\mathrm{a}}$ & $67.32^{\mathrm{a}}$ & 1.705 & * \\
\hline U. $\mathrm{N}_{2}(\mathrm{~g})$ & $0.94^{\mathrm{b}}$ & $1.05^{\mathrm{a}}$ & $0.97^{\mathrm{b}}$ & $1.06^{\mathrm{a}}$ & $1.08^{\mathrm{a}}$ & $1.11^{\mathrm{a}}$ & 0.0294 & * \\
\hline PI (g) & $35.00^{\mathrm{a}}$ & $30.39^{\mathrm{b}}$ & $28.91^{\mathrm{b}}$ & $30.37^{b}$ & $28.31^{\mathrm{b}}$ & $23.71^{\mathrm{c}}$ & 23.71 & * \\
\hline FP (g) & $6.87^{\mathrm{a}}$ & $5.57^{\mathrm{b}}$ & $5.22^{\mathrm{b}}$ & $5.18^{\mathrm{b}}$ & $5.95^{\mathrm{ab}}$ & $6.19^{\mathrm{ab}}$ & 0.3131 & * \\
\hline $\mathrm{N}_{2}-\operatorname{Int}(\mathrm{g})$ & $5.60^{\mathrm{a}}$ & $4.86^{\mathrm{b}}$ & $4.61^{\mathrm{b}}$ & $4.86^{\mathrm{b}}$ & $4.53^{\mathrm{b}}$ & $3.79^{\mathrm{c}}$ & 0.1902 & * \\
\hline F.N $N_{2}(g)$ & $1.09^{\mathrm{a}}$ & $0.89^{\mathrm{b}}$ & $0.83^{\mathrm{b}}$ & $0.84^{\mathrm{b}}$ & $0.94^{\mathrm{ab}}$ & $1.01^{\mathrm{ab}}$ & 0.0525 & * \\
\hline $\mathrm{N}_{2}-\operatorname{Ret}(\mathrm{g})$ & $3.57^{\mathrm{a}}$ & $2.92^{\mathrm{ab}}$ & $2.84^{\mathrm{ab}}$ & $2.91^{\mathrm{ab}}$ & $2.51^{\mathrm{ab}}$ & $1.69^{\mathrm{c}}$ & 0.2159 & * \\
\hline $\begin{array}{l}\text { N retained } \\
\text { (\% intake) }\end{array}$ & $63.75^{\mathrm{a}}$ & $60.08^{\mathrm{ab}}$ & $61.61^{\mathrm{ab}}$ & $59.88^{\mathrm{ab}}$ & $55.41^{\mathrm{ab}}$ & $44.59^{c}$ & 1.432 & * \\
\hline
\end{tabular}

DMI=Dry matter intake, FOPT=Faecal output, U.Vol=Urinary volume, Dig. =Digestibility, U. N2=Urinary nitrogen, $\mathrm{PI}=$ Protein intake, $\mathrm{FP}=$ Faecal protein, N2-Int=Nitrogen intake, F.N2=Faecal nitrogen, N2-Ret=Nitrogen retention Means in the same raw with different superscripts differ significantly $(\mathrm{P}<0.05)$

Table 3: Effects of Treatments on nutrients utilization by goats

Table 4 shows the effects of the treatment diets on hematological indices of the experimental animals. The packed cell volume (PCV) for all the animals on the treatment diets ranged from 24-39.5\%. This falls within the 22-38\% range for healthy goats [20]. The author stated that anything below this range results in anemia. As a result, oxygen carrying capacity of the blood is reduced with consequent increase in pulse rate and heart failure. It is also found that blood urea ranged from 18-25 mg which is within the normal range for goats [27]. It is also found that blood protein and glucose fell in the ranges of 3-5mg/dl and 4-6mg/dl respectively which are in the normal ranges of $3-8 \mathrm{mg} / \mathrm{dl}$ and $48 \mathrm{mg} / \mathrm{dl}$ respectively [28]. They stated that feed low in Metabolizeable energy (ME) significantly increase the level of blood urea-nitrogen and serum creatine and lower serum protein concentration. Therefore, since these are in the normal ranges the energy and protein levels are adequate to maintain the normal metabolism of the animals.

\begin{tabular}{|c|c|c|c|c|c|c|c|c|}
\hline \multicolumn{7}{|c|}{ TREATMENTS } \\
\hline Parameters & $\mathrm{T}_{1}$ & $\mathrm{~T}_{2}$ & $\mathrm{~T}_{3}$ & $\mathrm{~T}_{4}$ & $\mathrm{~T}_{5}$ & $\mathrm{~T}_{6}$ & SEM & Sig Level \\
\hline PCV (\%) & $24.50^{\mathrm{b}}$ & $37.75^{\mathrm{a}}$ & $30.00^{\mathrm{ab}}$ & $26.50^{\mathrm{b}}$ & $39.50^{\mathrm{b}}$ & $26.26^{\mathrm{b}}$ & 0.5334 & $*$ \\
\hline Hb (\%) & $11.25^{\mathrm{ab}}$ & $15.15^{\mathrm{a}}$ & $14.25^{\mathrm{a}}$ & $8.55_{\mathrm{b}}$ & $13.63^{\mathrm{b}}$ & $7.93^{\mathrm{b}}$ & 0.6328 & $*$ \\
\hline RBC x106 & $3.85^{\mathrm{b}}$ & $6.50^{\mathrm{a}}$ & $4.70^{\mathrm{b}}$ & $4.65^{\mathrm{b}}$ & $4.75^{\mathrm{b}}$ & $4.58^{\mathrm{b}}$ & 0.4879 & $*$ \\
\hline WBC X109 & $8.30^{\mathrm{d}}$ & $13.60^{\mathrm{a}}$ & $11.05^{\mathrm{bc}}$ & $9.53^{\mathrm{bc}}$ & $11.80^{\mathrm{a}}$ & $9.31^{\mathrm{dc}}$ & 0.7078 & $*$ \\
\hline Bld prot (mg/dl) & $3.65^{\mathrm{ab}}$ & $5.13^{\mathrm{a}}$ & $4.25^{\mathrm{ab}}$ & $2.96^{\mathrm{b}}$ & $4.29^{\mathrm{a}}$ & $3.78^{\mathrm{ab}}$ & 0.3738 & $*$ \\
\hline Total protein $\mathbf{m g} / \mathbf{d l}$ & 3.55 & 7.25 & 5.34 & 3.82 & 5.02 & 4.66 & 0.562 & $*$ \\
\hline Albumen $(\mathbf{m g} / \mathbf{d l})$ & $1.70^{\mathrm{b}}$ & $4.10^{\mathrm{a}}$ & $2.73^{\mathrm{b}}$ & $2.01^{\mathrm{b}}$ & $2.49^{\mathrm{b}}$ & $2.38^{\mathrm{b}}$ & 0.5957 & $*$ \\
\hline Globulin (mg/dl) & $1.85^{\mathrm{b}}$ & $3.15^{\mathrm{a}}$ & $2.61^{\mathrm{ab}}$ & $1.81^{\mathrm{b}}$ & $2.53^{\mathrm{ab}}$ & $2.28^{\mathrm{ab}}$ & 0.4738 & $*$ \\
\hline Glucose (mg/dl) & $4.30^{\mathrm{b}}$ & $6.10^{\mathrm{a}}$ & $4.20^{\mathrm{b}}$ & $4.48^{\mathrm{b}}$ & $4.98^{\mathrm{b}}$ & $4.18^{\mathrm{b}}$ & 0.5863 & $*$ \\
\hline Blood urea (mg/dl) & $22.69^{\mathrm{b}}$ & $25.00^{\mathrm{a}}$ & $24.36^{\mathrm{a}}$ & $22.55^{\mathrm{b}}$ & $21.88^{\mathrm{b}}$ & $18.00^{\mathrm{b}}$ & 0.5563 & $*$ \\
\hline
\end{tabular}

$\mathrm{PCV}=$ Packed cell volume, $\mathrm{Hb}=$ Haemoglobin, $\mathrm{RBC}=$ Red blood cell counts, WBC $=$ White blood cell counts, Bld prot=Blood protein

Means in the same raw with different superscripts differ significantly $(\mathrm{P}<0.05)$

Table 4: Effects of Treatments on Hematological and serum biochemical indices of the Red Sokoto goats 
The globulin level is found to be low, in the range of $2-3 \mathrm{mg} / \mathrm{dl}$. Oduguwa, et al. reported that level of protein intake has significant effect on total plasma protein [27]. According to the authors, plasma protein partakes in nutrition by functioning as a pool for amino acids and other tissue protein. Lower values for albumin has physiochemical function in maintaining colloidal osmotic pressure which is required to maintain blood volume. In this experiment, the hemoglobin level is $7.93-15.15 \mathrm{~g} / \mathrm{dl}$ across treatments which fall within the normal range of $7.5-15 \mathrm{~g} / \mathrm{dl}$ for healthy goats [29]. This confirms the findings of Yusuf, et al. that blood profile of animals often reflects their nutritional adequacy or otherwise. Dietary components have measurable effects on blood constituents such that significant changes in their values can be used to draw inference on the nutritive values of feeds offered to the animals [20].

Lawrence-Azua, et al. further stated that blood is an important index of physiological, pathological and nutritional status in the organism and the blood variables most consistently affected by dietary influence are Red Blood Cells (RBC), Packed Cell Volume (PCV) and Plasma proteins [30].

\section{Conclusion}

It is concluded that the treatments diets were able to supply the needed nutrients which enabled the animals maintain the normal healthy blood profiles. The animals therefore utilized the feed for maintenance and increase in weights effectively. Therefore, to reduce cost and increase profitability, maize cob with very low or no cost, could replace up to $50 \%$ of more expensive maize bran in the diet of Red Sokoto goats.

\section{References}

1. FAO (Food and Agricultural Organization) (2006) Official Statistics, Rome.

2. Oni, O.O. (2002) Breeds and genetic improvements of small ruminants (Sheep and Goats). A paper presented at small ruminants training workshop held at NAPRI, ABU Zaria, 45-7.

3. Franz C, Garza-Cares F, Hernandez-Vidal G, Olivares-Saenz E, Fimbres-Durazo H, et al. (2004) Intake, Digestibility and Ruminal Fermentation of ground and whole Maize Bran fed to American Alpine Goats. S Afr J Anim Sci 2004: 78-81.

4. Adeloye AA (1994) the influence of varying ratios of Cowpea husk and Maize Milling Waste on feed intake, protein and energy utilization by goats. Niger J Anim Prod 21: 1994.

5. Tuah AK (2007) Utilization of Agricultural by-products for village and commercial Production of sheep rations in Ghana.

6. Yahaya MS, Aliyara YH, Ardo MB, Nyako H, Ibrahim CJ, et al. (2001) Growth performance and cost effectiveness of rams fed groundnut hay supplemented with equal quantities of maize offal in North Eastern Nigeria. Malays J Ani Sci 7: 121-3.

7. Otor UJ, Patricia A, Gabriel MB (1990) Substitution of maize offal for Maize in the diets of laying hens. Niger J Anim Prod Re 17: 56-60.

8. Urior NA, Kategile JA (2005) Maize Stover and cobs as feed resources for Ruminants in Tanzania.

9. Bareeba FB and Mugerwa JS (2007) Use of research results to formulate a Feeding strategy for livestock during the dry season in Uganda.

10. Tuah AK, Orskov ER (2005) The degradation of untreated maize cobs and Cocoa pod husk in the rumen. FAO Corporate Document Repository, FAO, Rome, Italy.

11. Adebowale EA (2005) Maize residues as ruminant feed resources in Nigeria. FAO Corporate Document Repository.

12. Kinfemi AA, Mohammed MI, Ayoade JA (2009) Biodegradation of Cowpea Shells by Pleurotus spp for its use as ruminants feed. World J Agri Sci 5: 639-45.

13. Bunmi SM, Lawrence, Clarence L, Aduli E, Othniel M (2008) Chemical Composition, feed intakes and digestibility of crop residues based rations in Non-lactating Red Sokoto goats in the sub-humid zone of Nigeria. Anim Sci J 74: 89-94.

14. Cassey NH, Niekerk VWA (1999) The Boer goat, growth, nutrient Requirements and meat quality performance test and origin. University Of Pretoria, South Africa.

15. Rick M, Ferrell D, Bob D, Uvalde ER (1995) Growth and carcass Characteristics of Spanish $1 / 4$ and $1 / 2$ Boer withers after 66 days on feed. Bandera County.

16. McDonald P, Edward RA, Greenhalgh JFD, Morgan CA (2002) Animal Nutrition (6 ${ }^{\text {th }}$ Edn) Prentice Hall, United Kingdom. 235-40.

17. Yashim SM, Abubakar, H, Abdu SB (2011) Effect of Crotolaria retusa to Concentrate ratio fed to Red Sokoto Goats on Digestibility. Nig J Animal Sci 113: 162-8.

18. Ojebiyi OO, Emiola IA, Rafiu TA, Hamzat RAH, Ademowa IO (2009) Growth, Haematological and serum Biochemical Responses of Broiler Chickens fed graded levels of Kola (Cola acuminata) husk meal. Trop J Animal Sci 2: 110-11.

19. Abegunde TO (2008) Digestibility and Haematological response of West African Dwarf goats to Ficus polita leaves and Panicum maximum diets. Proceedings of the 13th Annual Conference of Animal Science Association of Nigeria held A.B.U. Zaria, 123-5.

20. Yusuf AO, Aina ABJ, Yeku SA, Ero-Samuel, BD (2012) Haematological Indices and Blood Biochemistry of West African Dwarf Rams fed Grass/Concentrate mixture. Proceedings of the $17^{\text {th }}$ Annual conference of Animal Science Association of Nigeria held at Abuja, 188-90.

21. Saidu I, Gadiga BL (2004) Population: A write up in Mubi region, A Geographical synthesis by Adebayo, A.A. Published by Paraclette Publishers Yola. 117-9.

22. AOAC (2005) Association of Official Analytical Chemists. Official Methods of Analysis. 18 $8^{\text {th }}$ Edition, AOAC, International, Maryland, USA.

23. Oni AO, Arigbede OM, Sowande OS, Anele UY, Aderinboye RY, et al. (2010) Histopathological and Serum Biochemical parameters of West African Dwarf goats fed dried cassava Leaves based concentrates diets. Trop Anim Health Prod 44: 123-5.

24. Fasuyi AO, Ibitayo FJ, Alo OS (2010) Histopathological and haematological implications of feeding wild sun flower (Tithonia diversifolia) leaf meal to growing pigs. Proceedings of the $15^{\text {th }}$ Annual conference of Animal Science Association of Nigeria held at University of Uyo, 233-6.

25. SAS (2001) Statistical Analysis System, SAS 2001, SAS/STAT Software Release 8.02. SAS Institute Inc. Cary, NC. USA.

26. Gibson AT (2007) Meat goats Breeds and Breeding plans. Agricultural Research Services, United States Department of Agriculture.

27. Oduguwa BO, Amole AO, Okwelum N, Shittu OO, Ogunlolu, et al. (2012) Performance and Blood Chemistry of West African Dwarf Goats Fed Varying Levels of Pineapple and Cassava Peel wastes Basal Diets. Proceedings of the $17^{\text {th }}$ Annual Conference of Animal Science Association of Nigeria (ASAN) held at Abuja. 607-9. 
28. Finangwai HI, Ehoche OW, Akpa GN (2010) Effect of Urea Treated Maize Stover Based Complete Diets on the Biochemical changes in the Rumen and Blood Parameters of Cross-bred Bulls. Proceedings of the $15^{\text {th }}$ Annual Conference of Animal Science Association of Nigeria (ASAN) held at University of Uyo, 609-10.

29. Daramola JO, Adeloye AA, Fatoba TA, Soladoye AO (2005) Haematological and Biochemical Parameters of West African Dwarf goats. Livestock Research For Rural Development 17: 89-92.

30. Lawrence-Azua OO, Odetola OM, Adedeji OY, Yahaya MO (2012) Growth and serum Biochemical Indices of growing Rabbits fed Enzyme Supplemented with cocoa bean shell. Proceedings of the $17^{\text {th }}$ Annual Conference of Animal Science Association of Nigeria held at Abuja, 458-9. 